Journal

of Geography,

Politics and Society

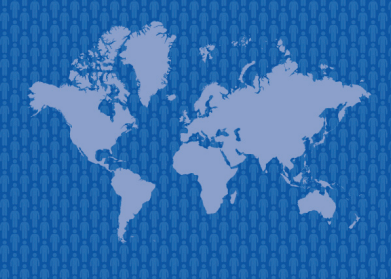

$10(4) / 2020$

\section{Journal of Geography, Politics and Society}

2020, 10(4), 33-48

https://doi.org/10.26881/jpgs.2020.4.05

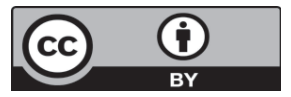

\title{
CONTESTED IDENTITIES AND SYMBOLIC CHANGES IN THE URBAN SPACE OF BYTOM (POLAND). THE HISTORICAL-GEOGRAPHICAL APPROACH
}

\author{
Marzena Lamparska \\ Institute of Social and Economic Geography and Spatial Management, Faculty of Natural Sciences, University of Silesia, Będzińska 60, 41-205 Sosnowiec, Poland, \\ ORCID: 0000-0001-8574-9253 \\ e-mail: marzena.lamparska@us.edu.pl
}

\section{Citation}

Lamparska M., 2020, Contested identities and symbolic changes in the urban space of Bytom (Poland). The historical-geographical approach, Journal of Geography, Politics and Society, 10(4), 33-48.

\begin{abstract}
Bytom is a city located in Upper Silesia, in the southern part of Poland which after World War II found itself within the boundaries of Poland after several hundred years. For many centuries, the main function of the city has been metal-ore and hard coal mining, which considerably contributed to its historical identity. The over 800 -year history is full of numerous social, economic and ethnic conflicts caused by frequent changes in the city's political affiliation and frequent redefinitions of its identity. After the collapse of communism, during the political and economic transformation, there arose a need to determine a new development path, in particular a new perspective on the heritage from the times of German dominance and from the times of communism. The mining and heavy industries have already ceased to be the basis of Bytom's identity. Taking account of these historical rationales, this article attempts to answer the question of whether, among a number of contradictions and conflicts, the urban community of today's Bytom, heterogeneous in terms of its origin, will be able to generate a model of cultural identity and historical remembrance accepted by all. All these complex and the same time contradictory processes have been discussed through the prism of their reflection in the urban space and examined by means of historical analysis and contemporary cartographic and photographic sources.
\end{abstract}

\section{Key words}

identity, heritage, development path, questioning, contradiction, conflict.

\section{Introduction}

Research on the cultural identity and heritage of towns and cities serves scientific and social purposes. The research results play significant functions from the perspective of self-identification of urban communities and are useful in the reconstruction of history, in the cultivation of cultural heritage and in the formulation of development policies (Paasi, 2001). There are towns and cities which are characterized by numerous identities (Antonisich, Hoyler, 2019. These identities tend to contradict each other. The more political and ethnic changes there are, the more complex a town's identity is (Ufer, 2015). This problem is particularly apparent in towns and cities of Upper Silesia. As a result of peace agreements 
after World War II, this whole region, including Bytom, was attached to the Polish State. Over the previous centuries, towns located in Upper Silesia had remained outside Polish administration (MurzynKurpisz, Gwozdż, 2011).

The study has two objectives that are strictly related to each other. The first one is to identify conflicts related to frequent changes in the political affiliation of the city and its identity. The second objective is to track how these conflicts and changes are recorded in the urban space, in selected historical periods and today. The record of conflicts, manners of questioning identity, cultural heritage and history may be analysed on maps of the city from different periods.

\section{Materials and methods}

The geographical identity of the city involves its location in space and duration of this space (Tuan, 1977). The urban identity is its genius loci. The genius loci parts include landscape, architecture, ethnic groups, communities, myths and superstitions (Baker, 1996; Madurowicz, 2017). In identification with the city, a large role is performed by the symbolic spaces through which it is recognizable and attracts or repels people from itself (Nawrocki, 2010). These particular generated symbolic spaces in cities facilitate people's identification with a given ethnic or social group, ideology, culture and religion (Monnet, 2011). One symbolic indicator of the city's identity is its landscape and heritage - the inalienable heritage of ancestors and the representation of particular values (Mitchell, 2005; Rębowska, 2002). These may be taken into consideration positively or negatively, as tangible and intangible, politically correct or not, and this has led to conflicts in public spaces (Harvey, 2001; Kisiel, 2019).

In summarizing this brief review of the literature, one may outline several remarks, significant for this article:

1. The identity of the city is multifaceted and arises from historical conditions (Bauman, 1998; Massey et al. 1993).

2. Ipso facto, it may be contentious and full of various conflicts: ethnic, national, social or historical (Rampley (ed.), 2012; Polak-Springer, 2012).

3. It is representative of values which are current in contemporary society.

Bytom's symbolic spaces include squares, churches and their surroundings, cemeteries, city blocks intended for educational, administrative or military purposes, museums and monuments. For the needs of this article, field research and Author's observations, who has lived in Bytom since her birth, were combined with an analysis of city maps from 1927, 1934 and 1947 as well as OpenStreetMap from 2019 and 2020 (Beuthen..., 1927; Beuthen..., 1941; Planinformator..., 1947; OpenStreetMap, 2020). A review was carried out of selected symbolic spaces in Bytom which have been significant for the national identities of the city's inhabitants, focusing on the period from the 19th century to the 2020s.

\section{Results}

\subsection{Historical background}

It is impossible to take into consideration the identity of Bytom without mentioning the earliest and the latest dates setting out turning points in the city's history. One of the most important years was 1177, when Bytom was separated from the Małopolska (Lesser Poland) region and thereby from Poland. In 1945 , as a result of the Yalta Treaties, the city was amongst the territories granted to Poland, the socalled "regained lands" (Drabina, 2010). Between these two dates, its history followed a course of approximately 800 years outside Polish administration, culture and authority. Bytom was a multicultural city, inhabited mainly by Silesians, Germans, Jews, and Poles; it was also home to some Czechs and Hungarians.

In Bytom the cultural traditions of the indigenous population of this area, referred to as Silesians, were preserved. These people, speaking a language in which archaic Polish was mixed with Moravian and German loanwords, considered themselves as separate, not Polish or German, but Silesian (Kamusella, 2000). Silesians accounted for a considerable percentage of the city's population. They were mainly peasants, labourers and craftsmen who moved to Bytom in the age of industrialization from adjacent rural areas (Drabina, 2010). The German authorities refused them the right to a separate nationality and language, which was a source of numerous conflicts. After Bytom was joined to Poland, the same policy was followed by communist authorities. Also in the post-socialist period, Silesians are not considered an ethnic minority (Drabina, 2010; Kamusella, 1999, 2000, 2012; Ustawa ..., 2005). The germanisation of the 19th and early 20th centuries and the subsequent degermanisation of Upper Silesia after World War II have meant that each subsequent generation ended up with a different national identity, rendering it weaker than ethnic and group ties. After 1989, campaigns were launched to restore Silesia's autonomy, based on post-World War I peace treaties and the status quo ante of 1918-1939 but on new terms, including that of defining Silesians as a national or 


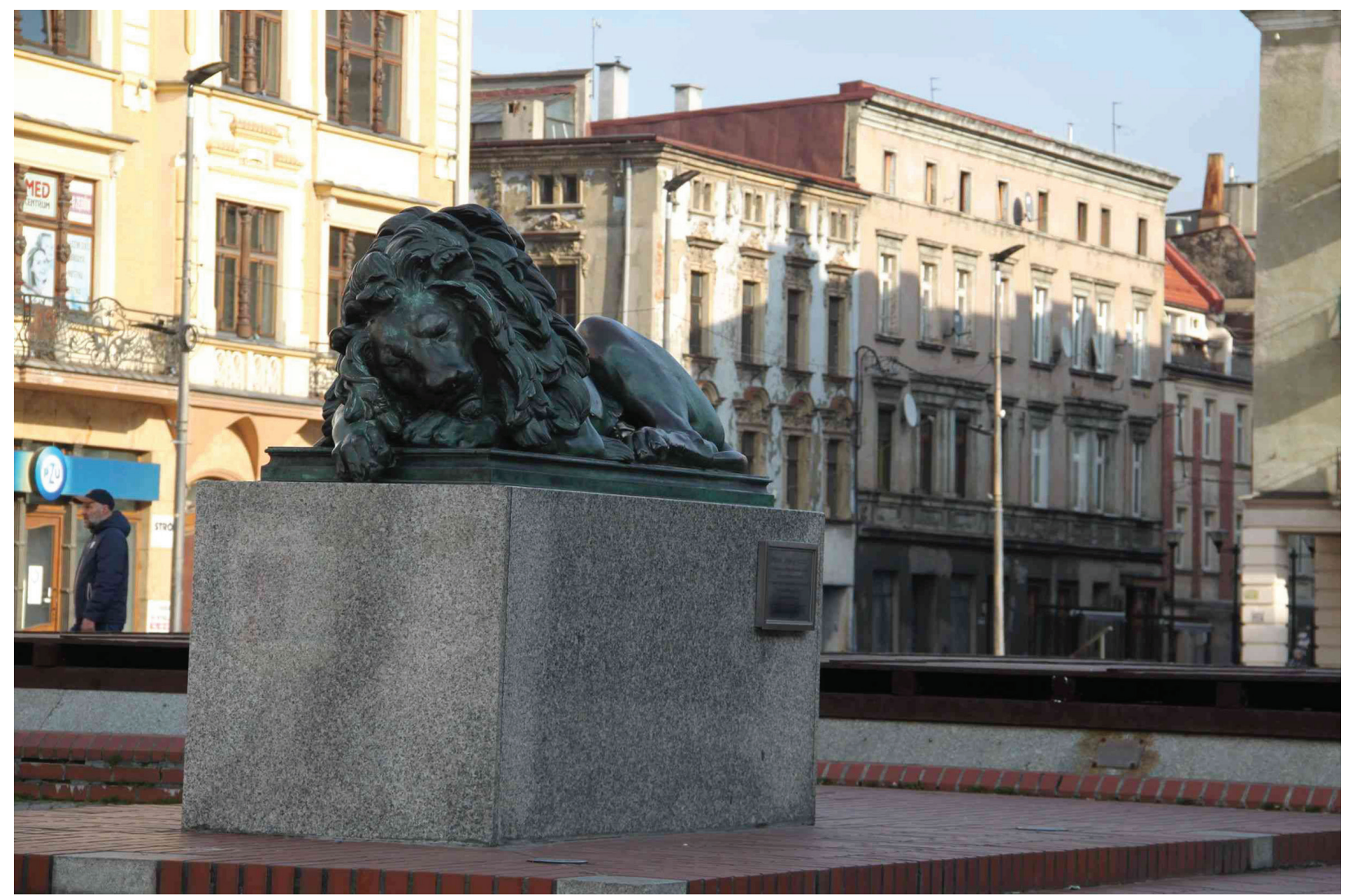

Fig. 1. The sleeping lion, Bytom, Main Square

Source: Photo by Author.

ethnic group'. Descendants of Polish and 'Eastern Borders' immigrants who came into Silesia after the end of World War II also consider themselves Silesians. Their identity can be difficult to define, and officially, they are identified by the region of their birth. Those groups invoke the multicultural nature of Silesia as the borderlands of cultures and nations.

The identity of Bytom is based on rights, traditions and the mining ethos. Periods of prosperity and downfall equally depended on the development of mining and industry as on politics (Molenda, 1972). Today, in the age of questioning the coal mining industry, Bytom is suffering a crisis, brought on by improperly conducted restructuring of this traditional sector of economy, which is reflected in conflict in the city (Krzysztofik et al., 2011; Lamparska, 2013).

\footnotetext{
1 Silesians can be considered a separate ethnic group under the modern definition of the term, as in recent years they have sought self-determination through highlighting the differences between them and the dominant ethnic group (Fenton, 2007). This has prompted strong criticism from Polish politicians, especially those from right-wing groups.
}

\subsection{Time of building the identity of a strong, German city}

From the beginning of the 19th century to the beginning of the 1940s, Bytom was developing as a German administrative and industrial centre. The greatest industrial and cultural boom took place in the period of the 2nd German Reich and the Weimar Republic (Beuthen..., 1914; Beuthen..., 1927).

The industrial potential, based on resources of hard coal deposits, zinc-ore and lead-ore (in total 11 mines) and iron-ore (90\% of the extraction in all of Germany) meant that the city saw a concentration of capital, scientific and administrative factors mainly originating from Germany. The authorities' care for urban order in Bytom, its infrastructure and financial resources, led to it being referred to as "little Berlin", partly resulting from the harmonious integration of impressive Art Nouveau and Bauhaus edifices with the architectural landscape of the city. In 1873, a monument was placed on Bytom's main square, which was crowned by the figure of a "sleeping lion", commemorating soldiers from the Bytom region who died in the Franco-Prussian war of 1870 and 1871 (Tab. 1, Fig. 2). On the one hand, the monument was an element of tribute to the fallen; on the other hand, the lion was an important symbol 
Tab. 1. Selected symbolic spaces in Bytom 1914-2020

\begin{tabular}{|c|c|c|c|c|}
\hline \multicolumn{5}{|c|}{ Symbolic spaces, buildings and monuments in Bytom, commemorating politic, enhnic and cultural conflicts, 1914-2020 } \\
\hline No & 1914-1927 & 1941 & 1947-1989 & 2020 \\
\hline 1 & Kaiser Frantz Josef Square & Adolf Hitler Square & $\begin{array}{l}\text { Marshal Stalin Square, } \\
\text { Kościuszki Square }\end{array}$ & Kościuszki Square \\
\hline 2 & Kaiser Square & Branauer Square & $\begin{array}{l}\text { Czerwony Square, } \\
\text { Sikorskiego Square }\end{array}$ & Sikorskiego Square \\
\hline 3 & Moldtke Square & Moldtke Square & $\begin{array}{l}\text { Sobieskiego Square, Thäl- } \\
\text { mann Square }\end{array}$ & Sobieskiego Square \\
\hline 4 & Ring Square, Rathaus & Ring Square, Rathaus & $\begin{array}{l}\text { Market Square, } \\
\text { Maciejowskiej Square }\end{array}$ & $\begin{array}{l}\text { Market Square. The commemo- } \\
\text { rative plaque with information } \\
\text { about the destroyed City Hall, } \\
\text { and the Sleeping Lion Monu- } \\
\text { ment are located here }\end{array}$ \\
\hline 4 & Ring Square, Rathaus & Ring Square, Rathaus & $\begin{array}{l}\text { Market Square, } \\
\text { Maciejowskiej Square }\end{array}$ & $\begin{array}{l}\text { Market Square. The commemo- } \\
\text { rative plaque with information } \\
\text { about the destroyed City Hall, } \\
\text { and the Sleeping Lion Monu- } \\
\text { ment are located here }\end{array}$ \\
\hline 5 & Reichpresidenten Square & Reichpresidenten Square & $\begin{array}{l}\text { Strzelców Bytomskich } \\
\text { Square, } \\
\text { Dzierżyński Square }\end{array}$ & Akademicki Square \\
\hline 6 & $\begin{array}{l}\text { Friedrich Wilhelm Ring, } \\
\text { Synagogue }\end{array}$ & Friedrich Wilhelm Ring & Grunwaldzki Square & $\begin{array}{l}\text { Grunwaldzki Square. } \\
\text { The commemorative plaque of } \\
\text { the Kristallnacht and the death } \\
\text { of Bytom Jews in the fascist } \\
\text { regime is located here }\end{array}$ \\
\hline 7 & Wilhelm Square & Wilhelm Square & Słowiański Square & Słowiański Square \\
\hline 8 & Kardinal Kopp Square & Kardinal Kopp Square & Bandurski Square & Rodła Square \\
\hline 9 & Kloster Square & Kloster Square & Klasztorny Square & Klasztorny Square \\
\hline 10 & Oberrealschule & $\begin{array}{l}\text { Adolf Hitler Städt Schule - } \\
\text { Oberschule für Jungen in } \\
\text { Beuthen }\end{array}$ & $\begin{array}{l}\text { General Sikorski Compre- } \\
\text { hensive School, }\end{array}$ & $\begin{array}{l}\text { General Sikorski Comprehen- } \\
\text { sive School }\end{array}$ \\
\hline 11 & $\begin{array}{l}\text { Realgimnasium - Polish } \\
\text { Comprehensive School }\end{array}$ & $\begin{array}{l}\text { Horst Wessel Schule stadt. } \\
\text { Oberschule für Jungen }\end{array}$ & $\begin{array}{l}\text { Jan Smoleń Comprehen- } \\
\text { sive School }\end{array}$ & $\begin{array}{l}\text { Jan Smoleń Comprehensive } \\
\text { School }\end{array}$ \\
\hline 12 & Lehrerinnenseminar & Lehrerinnenseminar & $\begin{array}{l}\text { Trade and Construction } \\
\text { Schools }\end{array}$ & Trade and Construction Schools \\
\hline 13 & Stadtpark & Stadtpark & Świerczewski Park & Franz Kachl Park \\
\hline 14 & Zivilgericht, Stadt Park & Katasteramt, Stadt Park & $\begin{array}{l}\text { Shaft Construction Com- } \\
\text { pany Management }\end{array}$ & $\begin{array}{l}\text { City Hall, Senior Mayor Heinrich } \\
\text { Bruning Square, Obelisk In } \\
\text { Memory of Victims of Commu- } \\
\text { nist Terror }\end{array}$ \\
\hline 15 & Strafgericht & Gefängnis & $\begin{array}{l}\text { (no information about this } \\
\text { place) }\end{array}$ & District Court \\
\hline 16 & Gefängnis & Gefängnis & $\begin{array}{l}\text { (no information about this } \\
\text { place) }\end{array}$ & Detention prison in Bytom \\
\hline 17 & $\begin{array}{l}\text { Oberschlesisches Landes- } \\
\text { museum }\end{array}$ & Landesmuseum, Moldtke & Silesian Museum in Bytom & Silesian Museum in Bytom \\
\hline 18 & Landratsamt/ Museum & Landratsamt/ Museum & $\begin{array}{l}\text { Office of Mining and Meas- } \\
\text { urement }\end{array}$ & $\begin{array}{l}\text { Branch of the Upper Silesian } \\
\text { Museum }\end{array}$ \\
\hline 19 & Konzerthaus & Konzerthaus & $\begin{array}{l}\text { Stanisław Moniuszko Sile- } \\
\text { sian Opera }\end{array}$ & $\begin{array}{l}\text { Stanisław Moniuszko Silesian } \\
\text { Opera }\end{array}$ \\
\hline 20 & $\begin{array}{l}\text { Garnison / Zoll- und Finan- } \\
\text { zamt }\end{array}$ & $\begin{array}{l}\text { Garnison / Zoll- und Finan- } \\
\text { zamt }\end{array}$ & $\begin{array}{l}\text { (no information about this } \\
\text { place) }\end{array}$ & City Hall \\
\hline
\end{tabular}




\begin{tabular}{|c|l|l|l|l|}
\hline 21 & $\begin{array}{l}\text { Oberstechnes Bahnhof } \\
\text { Square }\end{array}$ & $\begin{array}{l}\text { Oberstechnes Bahnhof } \\
\text { Square }\end{array}$ & Wolskiego Square & Wolskiego Square \\
\hline 22 & Jüdische Schule & Schule Jiserbach Str & $\begin{array}{l}\text { (no information about this } \\
\text { place) }\end{array}$ & Marketplace \\
\hline 23 & Jüdische Friedhof & Friedhof, & Jewish cemetery & Jewish Cemetery \\
\hline 24 & Evang. Friedhof & Evang. Friedhof & Evangelical Cemetery, & Evangelical Cemetery \\
\hline 25 & Ew. Kirche & Ew. Kirche & $\begin{array}{l}\text { St. Wojciech's catholic } \\
\text { church }\end{array}$ & St. Wojciech's catholic church \\
\hline
\end{tabular}

Source: Beuthen ...,1914; Beuthen...,1927; Beuthen O.S., 1941; Drabina, 2010, Plan-informator..., 1947, GoogleMaps, 2020; own study.

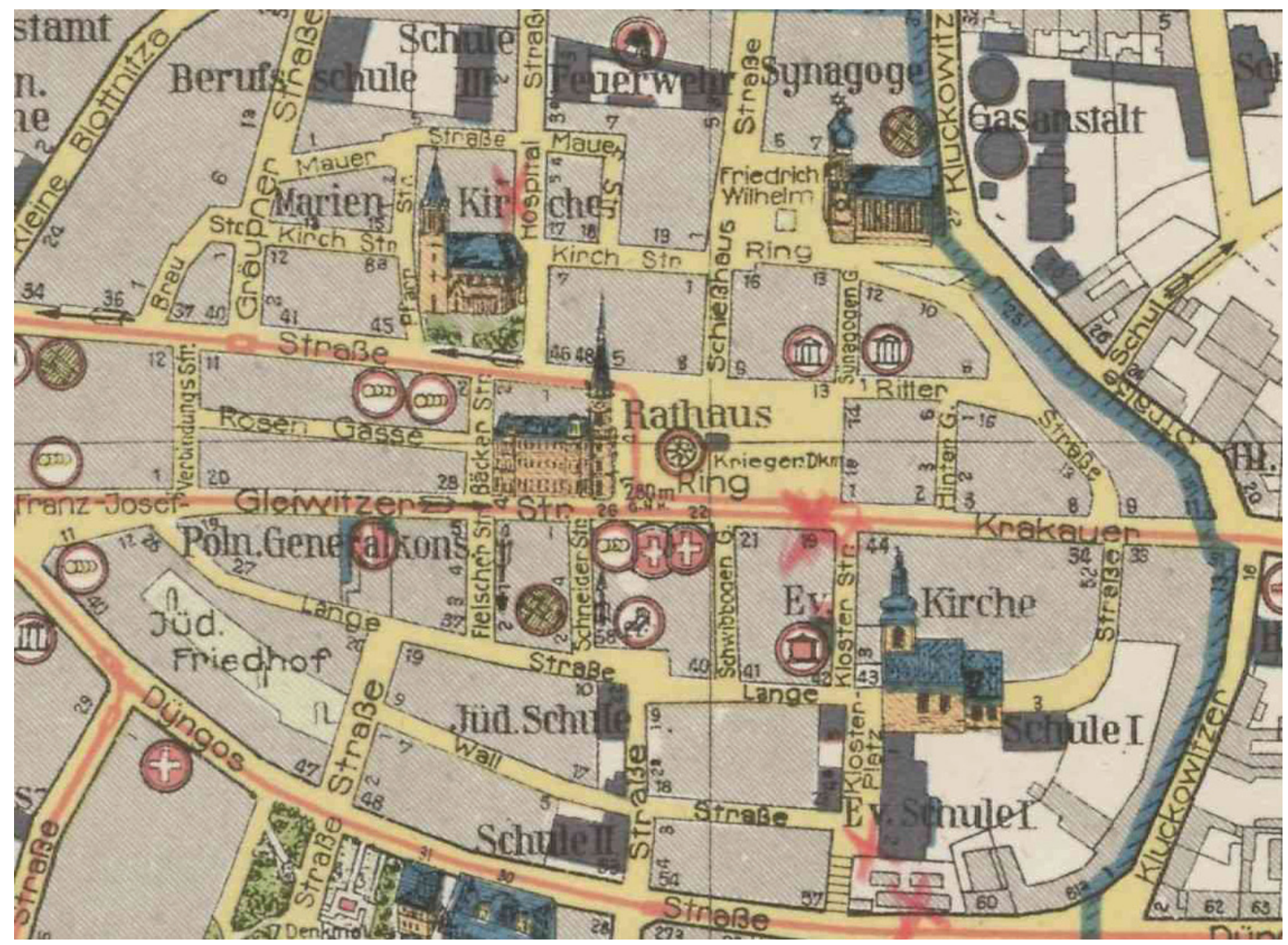

Fig. 2. Bytom, part of the city map in 1927

Source: Beuthen, 1927.

of the process of unification of Germany, an icon of national unity, situated in numerous German towns and cities which were involved in historic events significant from the perspective of German imperialism (Adamkiewicz, 2013).

The map of Bytom from 1927 tells us something about the relations between the then ethno-cultural identity and urban space. The most important monuments, as well as representative and functional spaces, were created based on German culture. They were located in the central part of the city, surrounding the market-square. Squares in Bytom bore the names of German and Prussian heroes and rulers, as did the streets. Modern urban planning schemes, projects drawn up on the drawing-boards of German designers, replaced the earlier buildings and moved into new spaces.

According to the assumptions of the law, the city was German, but it was inhabited by Jews, Silesians and Poles. On Friedrich Wilhelm Square, there was a synagogue, constituting the central part of the space associating Jews in Bytom. Jewish people were concentrated in regions marked out by Lange Street and Dangos Street, as well as side streets of Kaiser Square up to Goy Street (Fig. 2). 
There were schools, houses, bath-houses and a Jewish cemetery. Silesian people, working class, usually occupied districts in the vicinity of industrial plants situated on the outskirts of the city. The city was also home to Polish labourers who immigrated from the neighbouring Russian occupied land (and Poland since 1918) on promises of better work and living conditions. Most of these people were Catholic. Their religious and cultural activities were concentrated around Catholic churches, and adjacent organizations and schools. Priests who often originated from the local people created a space for the Polish language, which was the language of prayer, and for Silesian traditions in the increasingly Germanic city. Most German people in the city were also Catholics. There was one Evangelical chapel in the city and one church of this denomination (Beuthen..., 1927).

\subsection{Questioning of identity: the conflict between Polishness and the German policy}

There were frequent national conflicts in Bytom. Polish and German historians, J. Drabina (2010), L. Schofer (1975), and S. Michałkiewicz (ed., 1976), distinguish three significant periods in which these took place. The first one was evident from 1815. At that time, Bismarck's recommendations were introduced, pertaining to consolidation of the German community by combating linguistic and religious separateness. The obligation of education in German was introduced; this language was compulsory in public life, entailing the liquidation of Polish schools. The number of people speaking Polish decreased on a systematic basis: $1861-48.4 \%, 1871-45.8 \%, 1901$ - 38.08\% (Michałkiewicz (ed.), 1976). Cultural centres which were identified with Polishness included the editorial offices of magazines as well as Polish and Catholic publishing houses. As mentioned above, there were also Catholic parishes. Since the times of the Congress of Vienna, Bytom had been a garrison city for families of soldiers based there and living in Bytom, forming a significant group of residents speaking German only and constituting a close-knit community. The city's identity was meant to arise from governmental assumptions and to represent Germany and the German culture.

The second period began after World War I. This was a time of new political and cultural divisions, of establishing borders between the Weimar Republic and the revived Republic of Poland. According to the signatories of the Treaty of Versailles, a plebiscite was to decide on which country Bytom would belong to. The result of the vote was that the city remained in Germany, and the industrial areas were divided by political borders. The division by borders also involved mining sites. Customs posts were created underground (Lamparska, 2013). Bytom became a frontier symbol of Germany promoted by the government in Berlin. The obligation to use German in schools was continued. The Pedagogical Academy was established (1930), the first in Silesia and the second in Germany. A museum was established which, with the passing of time, became the most important centre of this type in German Upper Silesia.

Under the provisions of The German-Polish Convention on Upper Silesia, also known as the Geneva Convention, of 15 May 1922, Polish institutions were officially active in the space of Bytom. A Polish plebiscite commissariat, situated at the "Lomnitz" Hotel, still in existence at the Market Square, became a consulate of the Republic of Poland, while a seat of the Association of Poles in Germany was established, comprising Poles and Silesians who identified themselves with Polishness. A People's University was established, and in the early 1930s in Bytom, a Polish secondary school was created (information from a Commemorative Plaque placed on the building).

The third period of questioning the identity refers to the policy of German authorities of the Third Reich. In these times, Polishness and other cultures were eliminated from the city space. Directly before World War II, the city was one of the most populous metropolises of the German Reich, with 110,000 residents. The public spaces were dominated by fascist ideology (Fig. 3). The main representative square took the name of Adolf Hitler, until then known as Boulevard (Koścuiszki Square), as did the Oberrealschule (today the General Sikorski Comprehensive School, situated in Sikorskiego Square) (Tab. 1) (Beuthen..., 1941). In front of the Civil Court in the City Park (now the City Hall building), there stood a monument praising Horst Wessel (the author of lyrics to the song Horst-Wessel-Lied, which in the years 1933-1945 was sung as an unofficial anthem instead of the national anthem in Germany). In a wooden church in the Park dedicated to Saint Laurence (burnt in the 1950s by vandals), a place of remembrance was created for 1400 citizens of the city who died in World War I. In these circumstances, in the census of $1933,0.8 \%$ of residents declared Polish nationality. In 1938, the Kristallnacht took place, during which Jewish shops, city blocks and houses were destroyed and above all, a synagogue in the Moorish style, modelled on a famous Budapest synagogue, designed by Ludwig von Froster (Fig. 4, Fig. 5). This led to a conflict between the city authorities and the Jewish community which was expropriated. Despite efforts made, the community did not rebuild the synagogue. In its place, a market hall was to be 


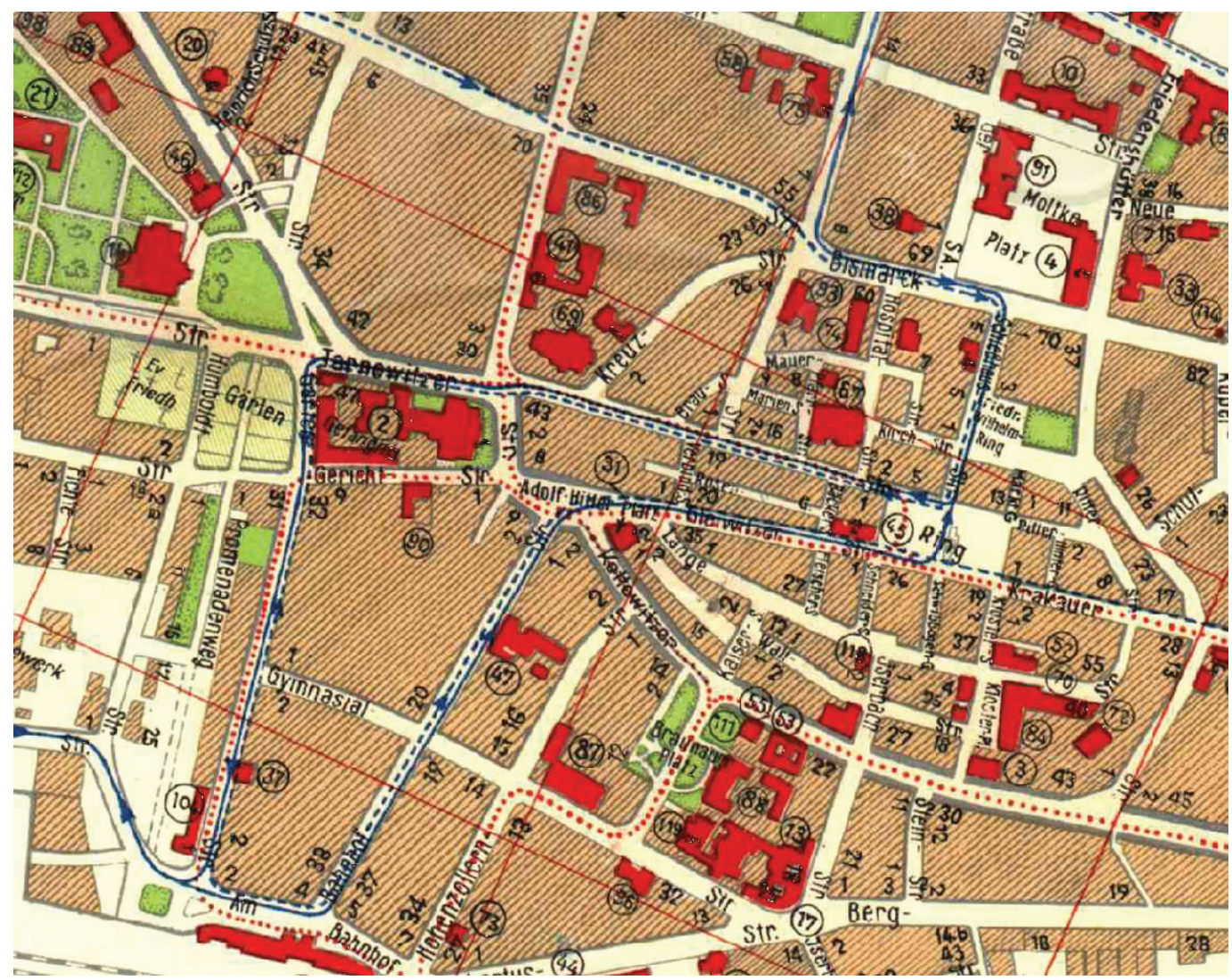

Fig. 3. Bytom Centre, part of the city plan in 1941 Source: Beuthen, 1941.

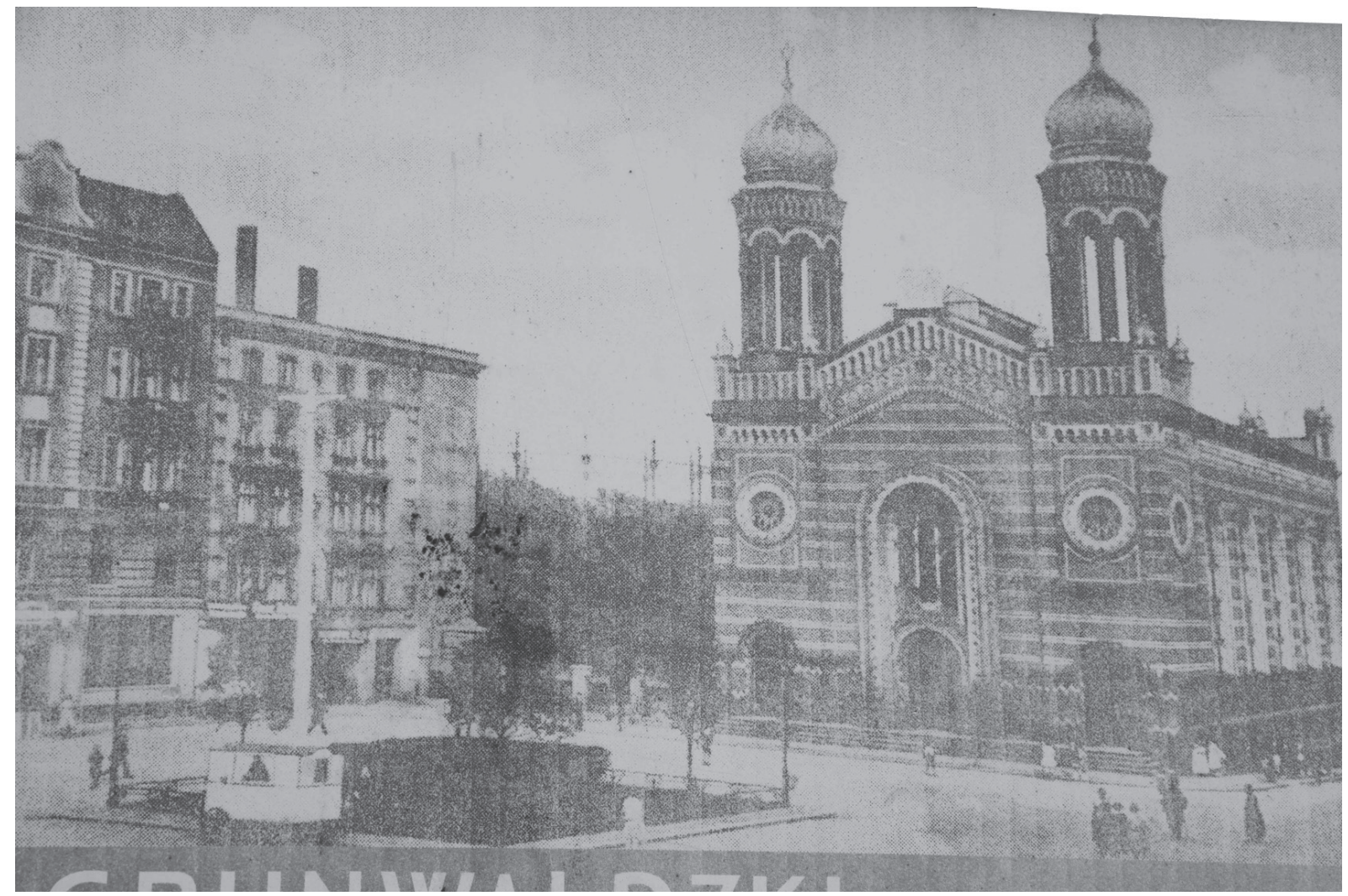

Fig. 4. Part of the commemorative plaque of the Kristallnacht and the death of Bytom Jews in the fascist regime with an archival photo of the Synagogue

Source: Photo by Author. 


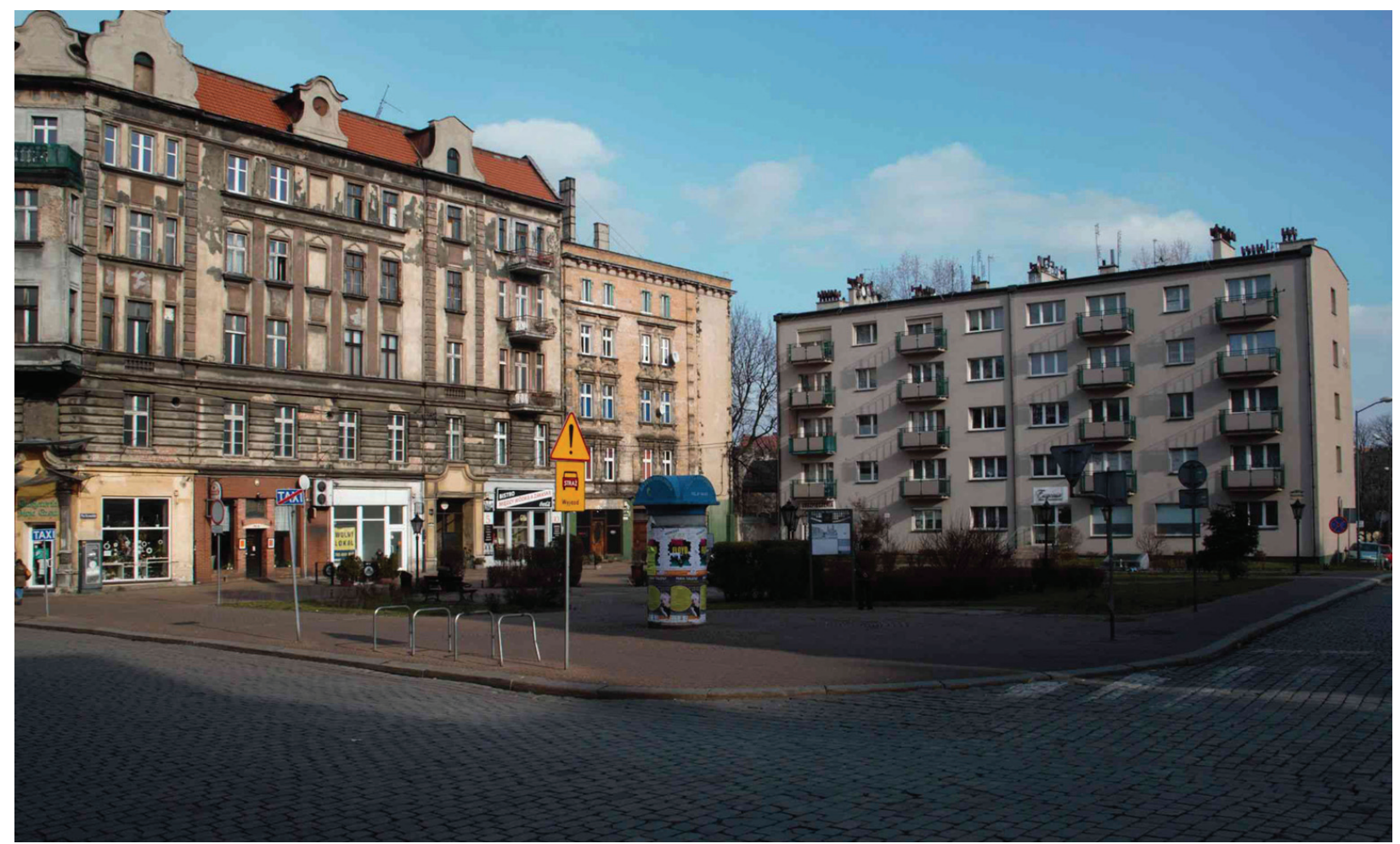

Fig. 5. Grunwaldzki Square. Location of the destroyed Synagogue

Source: Photo by Author.

established (Tab. 1). In 1942, as a result of the policy of the Holocaust, members of the Jewish community were transported to concentration camps (Cohen, Muller, 2016). The creation of a new cemetery, a non-religious one, was an expression of the fascist ideology.

\subsection{The socialist period: Bytom as a city forming part of the Polish identity}

The Red Army marched into Bytom in January 1945, and occupied the city until April of that year. The process of Germans leaving the city, commenced before the seizure of the city by the Soviets, continued. Before 1945, within the framework of German evacuation, approximately 11,000 people left the city (Konieczny, 1977). In 1946 and 1947, as part of the displacement policy, 25,000 people left Bytom (Drabina, 2010). These data are incomplete, and there is no information as to the number of people killed during the evacuation and resettlements. In 1945 , mass arrests and deportations to forced labour camps in the territory of the USSR began, conducted by Soviet security bodies and their subordinate officials of the Polish government in the region of Upper Silesia after the seizure of its area by the Red Army.

Most of the war destruction was concentrated in the city centre; Bytom's city hall was burnt down. In total, there were 120 demolished buildings in Bytom, 300 somewhat damaged and fit for reconstruction, whereas 80 were heavily damaged. Apart from the centre, the city did not suffer considerable damage during the warfare. The city hall and tenement houses surrounding it were destroyed. In spite of this, many valuable buildings survived (Buśkiewicz, 2013). As war reparations, the Soviets took away from Bytom whole industrial plants (smelters, coking plants, mine equipment, railway and municipal infrastructure). Soviet soldiers who died in fighting for Bytom were buried in the non-religious cemetery (created by the fascist government in 1941), in a compact quarter. Among their graves a monument with the red star was placed (Fig. 6).

In April 1945, the city became part of Poland. There was a change of cultural and political identity: according to the political narrative at the time, from a German city it became an ethnically Polish city returning to its motherland.

Officials from the Polish regional government in Bytom commenced registration of the population in the city for statistical and recording purposes. Silesians who wanted to stay were forced to prove their Polishness before a verification committee. Those who did not pass the verification were resettled in Germany. In the late 1940s the number of people verified amounted to 52,000 (Lippóczy, Walichnowski, 1982; Łempiński, 1979).

Poles arrived in Bytom from central Poland, Małopolska (Lesser Poland) and Świętokrzyskie 


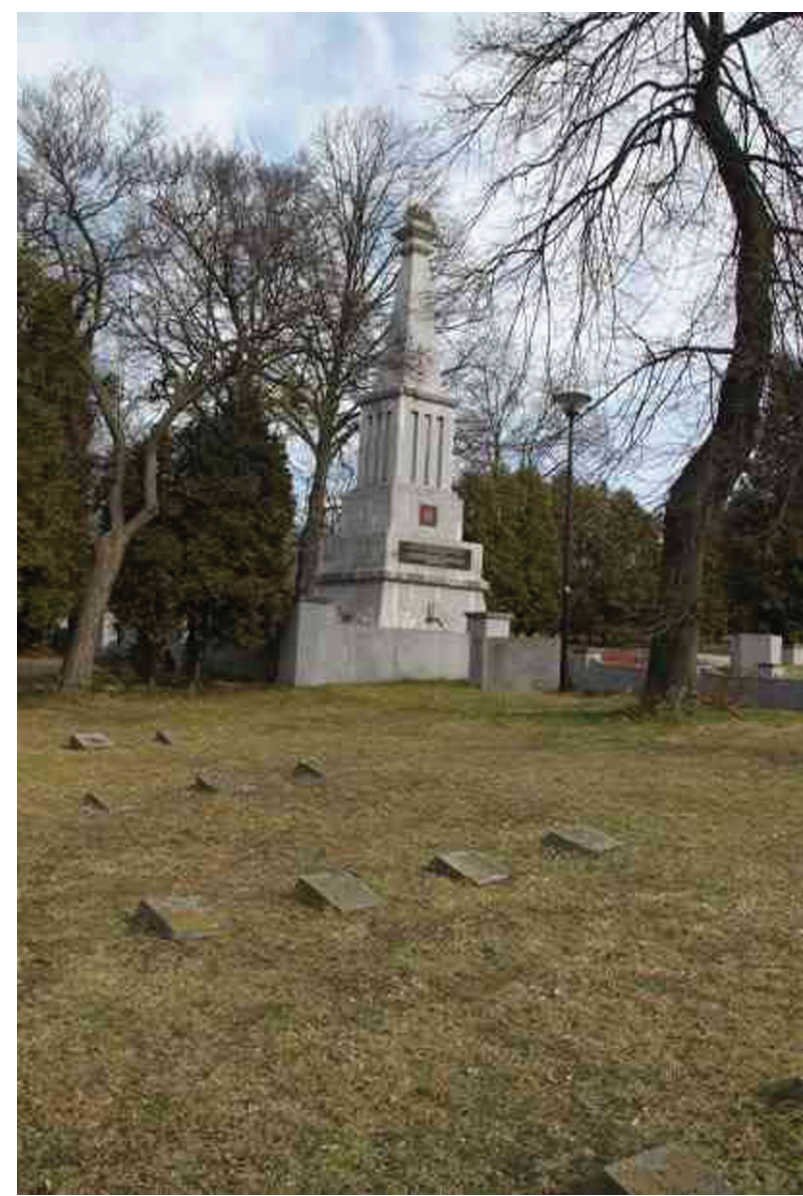

Fig. 6. War quarters of Soviet soldiers at the municipal cemetery in Bytom

Source: Photo by Author.

regions, motivated by the possibility of residing and taking on a well-paid job in mines. In 1948 their number was 22,000. These people caused numerous conflicts with Silesians, who were ruthlessly dispossessed by them and persecuted due to their Silesian accent and customs, different from those of Poles. This took place with the connivance of Polish authorities.

Polish people started to arrive in Bytom from eastern regions of interwar Poland, which under the Yalta Treaties became part of the Soviet Union (the so-called Eastern Borderlands). By 1948, more than 30,000 Poles from the Borderlands were living in Bytom. By 1948, nearly 11,000 people had returned from the West, including 4,500 miners from Belgium, France, and Germany (Drabina, 2010). In 1952-1964, as part of the settlement policy for Roma travellers, several dozen families were forcibly resettled in the city (Cyganie/Romowie..., 2011).

The city continued as an administrative, political, economic, mining as well as industrial and settlement centre. However, the civilizational and cultural continuity was broken. The German element was ousted from the cultural identity. The process of polonization of the symbolic space became a symptom of the conflict between the past and the new reality. This is shown by the city map of 1947 (Fig. 7, Tab. 1). This process lasted from 1945 to 1989 and included changes in the names of streets, squares, mines and industrial plants (Tab. 1). German technical and cultural attainments as well as historic monuments were denied and negated (Tab. 1). The names of streets and squares corresponded with the current political line and documented victory over the Germans. In this respect, research has shown the following regularities. The very centre of Bytom, its main square, was renamed to Marshal Stalin Square. Other streets and squares in the centre gained the names of Soviet liberators. Braunauer Square was renamed to Red Square. The main street of the city, Bismarck Street, was called Freedom Street (Tab. 1, Fig. 7).

Monuments and plaques commemorating events from the history of Germany were removed from the city, including the monument of the sleeping lion which became an ornament of the Warsaw Zoo. Even the evangelical church situated in Klasztorny Square became a Catholic temple (St. Wojciech Church).

After the war, Bytom became a working-class Polish city. The economic specialization became the main and almost sole criterion for determination of the city's identity. In general, the region became a framework for economic planning, a place for acquisition of raw materials and production of goods, an area attracting the labour force (Białasewicz, 2002). In the times of prosperity of the Polish coal mining industry, the city had 239,800 residents (1987), 2/3 of which were locals. The inflow of people from outside of Silesia caused cultural and ethnic conflicts. In those years, the city had a communist dimension -the mining ethos was complemented with a work ethic modelled on the Soviet Stakhanovites: races in productivity and speed of coal production. The most efficient mines were able to illuminate the red star on their main shaft - a symbol of socialist perfection (Lamparska, 2013).

In summarizing this period, it must be emphasized that after 1945 a new identity began to form, whose most elements were brought by those from the Eastern Borderlands, combined with local Silesian traditions. For those from the Eastern Borderlands, the architecture of Bytom was a reminder and perhaps compensation for the lost beauty and grand architecture of Lviv, Tarnopol and other Polish cities left in the East, though it did not replace the motherland for them. For Silesians, in turn, the architecture and landscape of the city were elements of their small motherland. The formation of this identity, 


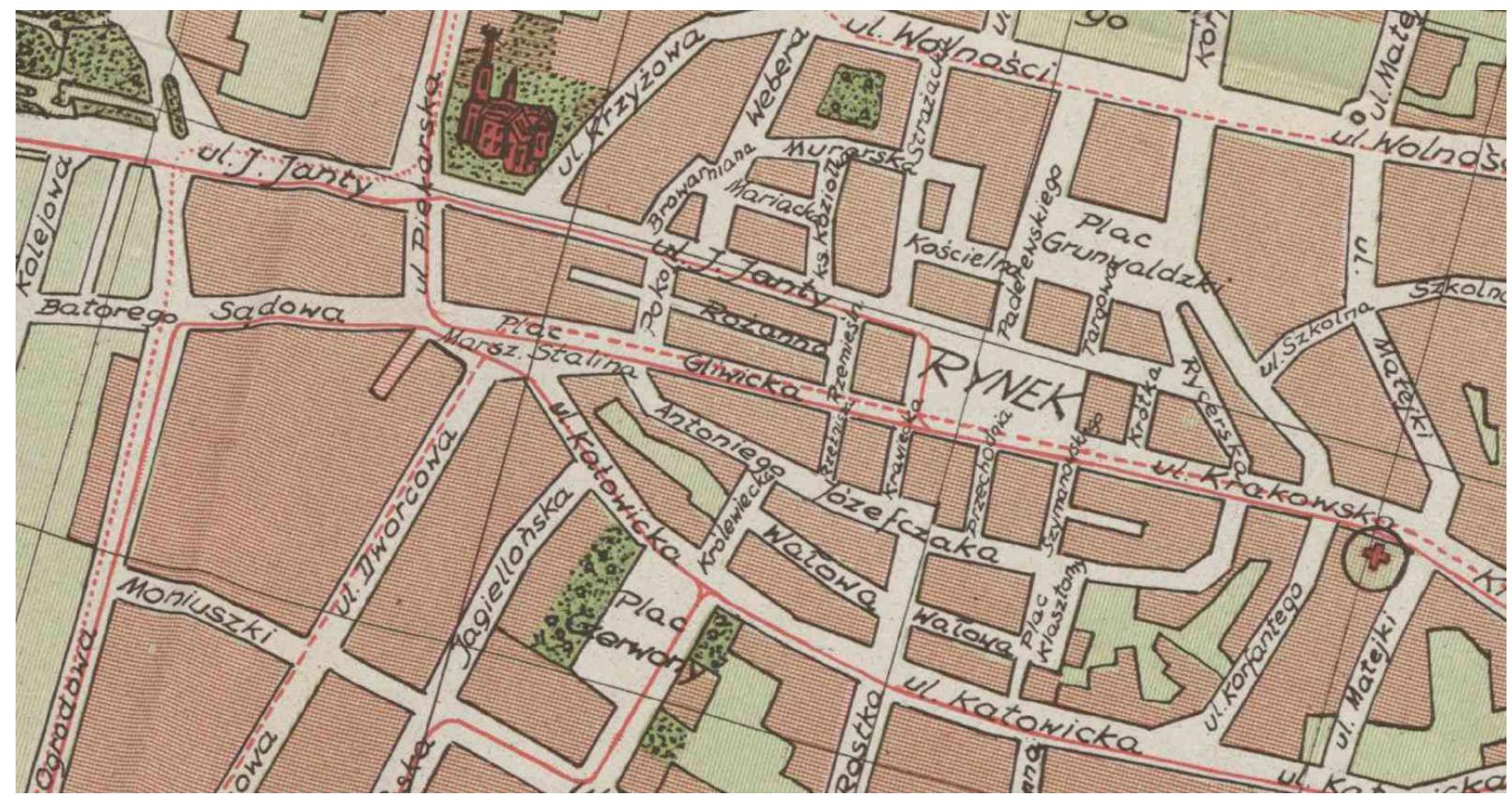

Fig. 7. Part of the Bytom 1947

Source: Plan-informator, 1947.

however, did not last, as the Polish government in Warsaw treated Silesia in categories of monoculture (Białasiewicz, 2002).

\subsection{Bytom in free Poland. (Almost) not a mining city anymore, so what kind of city?}

There was a conflict of values caused by negation of the mining identity and industrial output of the city in the 1990s. Liquidation of almost all the mines in Bytom led to huge unemployment among its residents, deterioration of the standard of living, and then a wave of emigration. Excessive development of the mining industry had become a reason for the material deterioration of the city (Tkocz, 1998).

After the collapse of communism, decentralization and territorial and administrative reform paved the way to a rediscovery of historical and cultural, regional and local specifics in post-communist countries, enabling collective self-identification with local and regional values. This was, in fact, a recovery of the past and a possibility to declare affiliation (Białasewicz, 2002).

At the beginning of the 1990s, the city started to gain a new identity. The decommunization process was reflected in the symbolic space of Bytom. Again, the names of squares, streets and even districts were changed, invoking the ethos of Borderlands people, heroes of Solidarity or Marshal Piłsudski (leader of the Polish State in the interwar period) and Pope John Paul II. There appeared symbols of the new identity in the urban space that are not connected with politics nor with mining. After
1990, Karin Stanek, a Silesian vocalist popular in Poland in the 1960s, was honoured; her monument is at the Bytom Centre of Culture. The Centre itself is a place focussed on avant-garde art and associated with the Bytom Theatre of Dance, known in Poland and abroad. Bytom has become the site of a sort of cultural revolution, consisting in breaking off from the mining and industry which defined the city so far. It has been an example which made one realize that a distinguishing feature of the post-industrial identity may be in avant-garde art.

Within the boundaries of Bytom, there has been a considerable change in the quality of the city space, caused by the de-urbanization process. The centre, despite being the location of the most important institutions, is largely neglected. This is the biggest challenge for the urban community, in particular in terms of historical remembrance and care. The shape of Bytom Market Square was changed when in the 1980s tenement houses on its southeast side were demolished without public consultation, though the decision of the city authorities was criticized (Fig. 8). The inhabitants of Bytom began to call this square "the red square". This colloquial name referred to the colour of paving stones.

On Kościuszki Square, partly in place of Art Nouveau tenement houses demolished in the 1980s, a shopping centre was erected in 2009. This new space disturbed the former, medieval urban layout. Along with revitalization, discussions about the identity of the city have intensified. These emphasise problems related to preservation of the industrial 


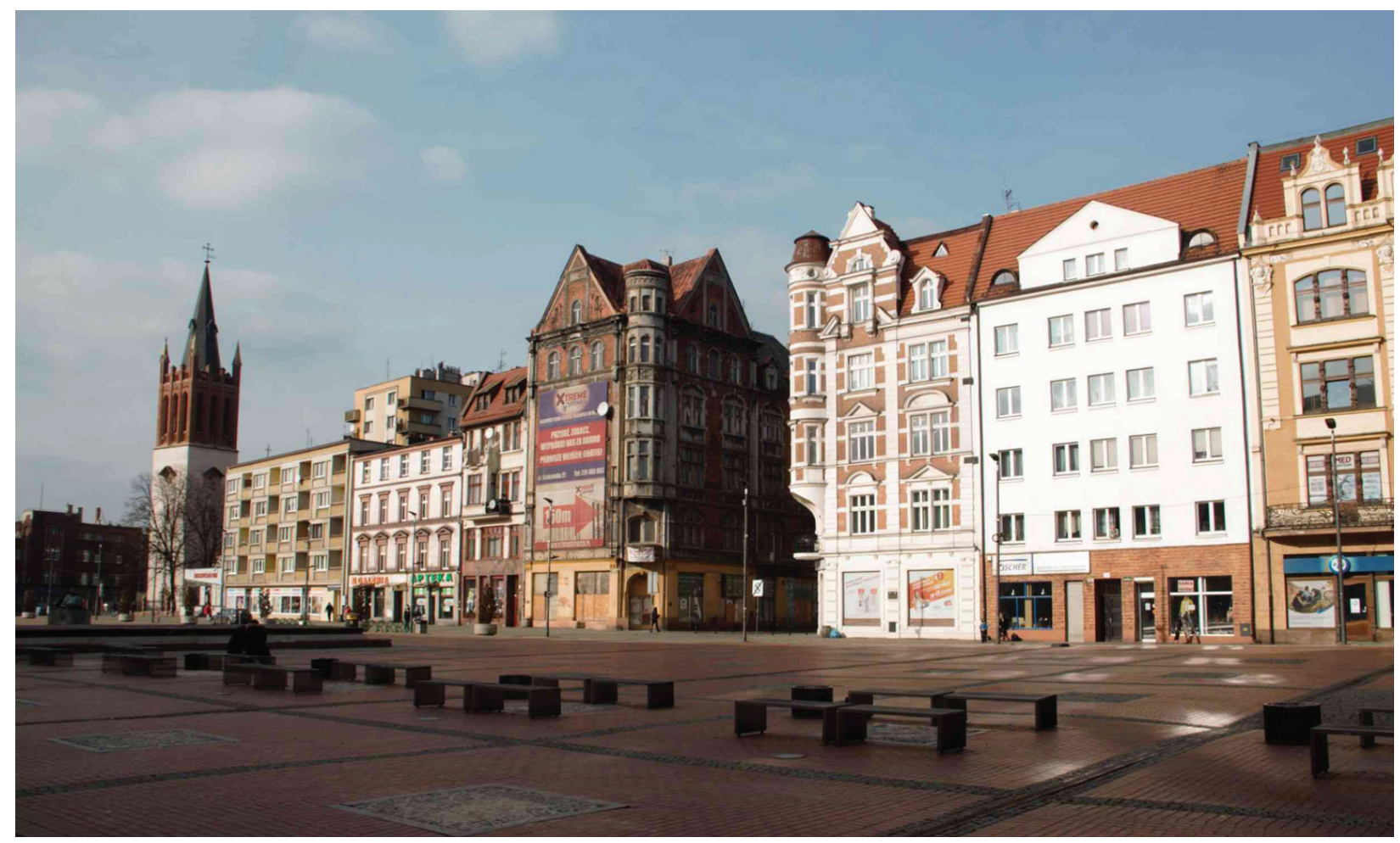

Fig. 8. Market Square in Bytom 2020

Source: Photo by Author.

heritage, reflecting conflicts taking place in other mining and industrial areas of Europe: there are too many sites, and revitalisation is too expensive. Although residents discern their historical and cultural value, they criticise the city authorities for passivity and selectivity in taking on protective actions.

The Bytom cemeteries of all denominations were not destroyed. Historic graves remain in the oldest Catholic cemetery, Mater Dolorosa. Unfortunately, the grave of Senior Mayor Bruning was destroyed. Graves of Polish soldiers from the times of World War II are located in a compact quarter. The section of German soldiers from the times of World War I has been preserved. The place of burial of Soviet soldiers in the municipal cemetery has fallen into oblivion.

\section{Discussion. Building a new identity in the space of Bytom. Between conflict and dialogue of various communities}

The issue of the identity of Bytom after 1990 currently involves the question of whether its re-conceptualisation may be based on the common heritage of several cultures, or will it remain a loose collection of particular cultural and historical identities. Accents referring to various periods in the history of Bytom and the traditions of ethnic groups living in this city are increasingly apparent in the symbolic space of
Bytom. This diversity is recorded in plans from before 1945 as well as on contemporary maps. The multicultural threads of the history of Bytom are more and more accentuated with pride in the city's policies (Tab. 1, Fig. 9).

Tab. 1 contains a list of 25 symbolic spaces that are documents of cultural and political conflicts that took place in the city. They are also urban landscape icons of Bytom. Figure 9 shows their location in the city space. The most important areas are squares, boulevards and parks, which are part of the urban system formed during the Second Reich and the Weimar Republic.

There is no longer a politically justified need for complete negation of the material heritage stemming from the times of the German dominance. A good example of the changes in this respect is in the naming of one of the major squares of the city given after Heinrich Bruning, senior mayor of Bytom, thanks to whom the city's period of prosperity started at the turn of the 20th century (Fig. 10).

The surnames of German architects, creators of residential quarters, parks and industrial zones returned to the public sphere. The German technical thought which shaped this space has been recognised.

A part of the heritage of Bytom is remembrance of the Kristallnacht and extermination of the Jewish community. This event is marked out by a memorial 


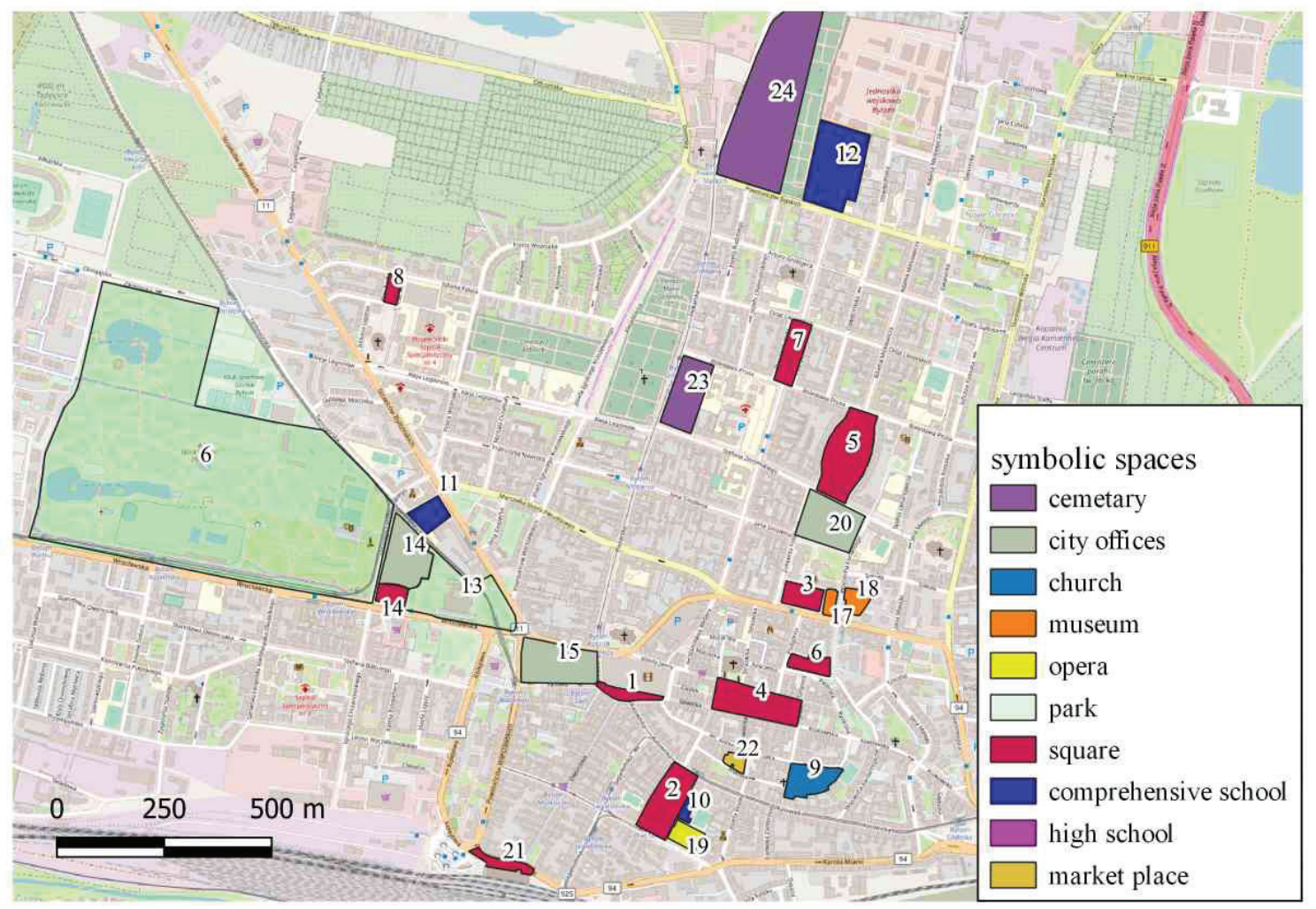

Fig. 9. Symbolic spaces in Bytom 2020, included in Table 1 Source: Own study.

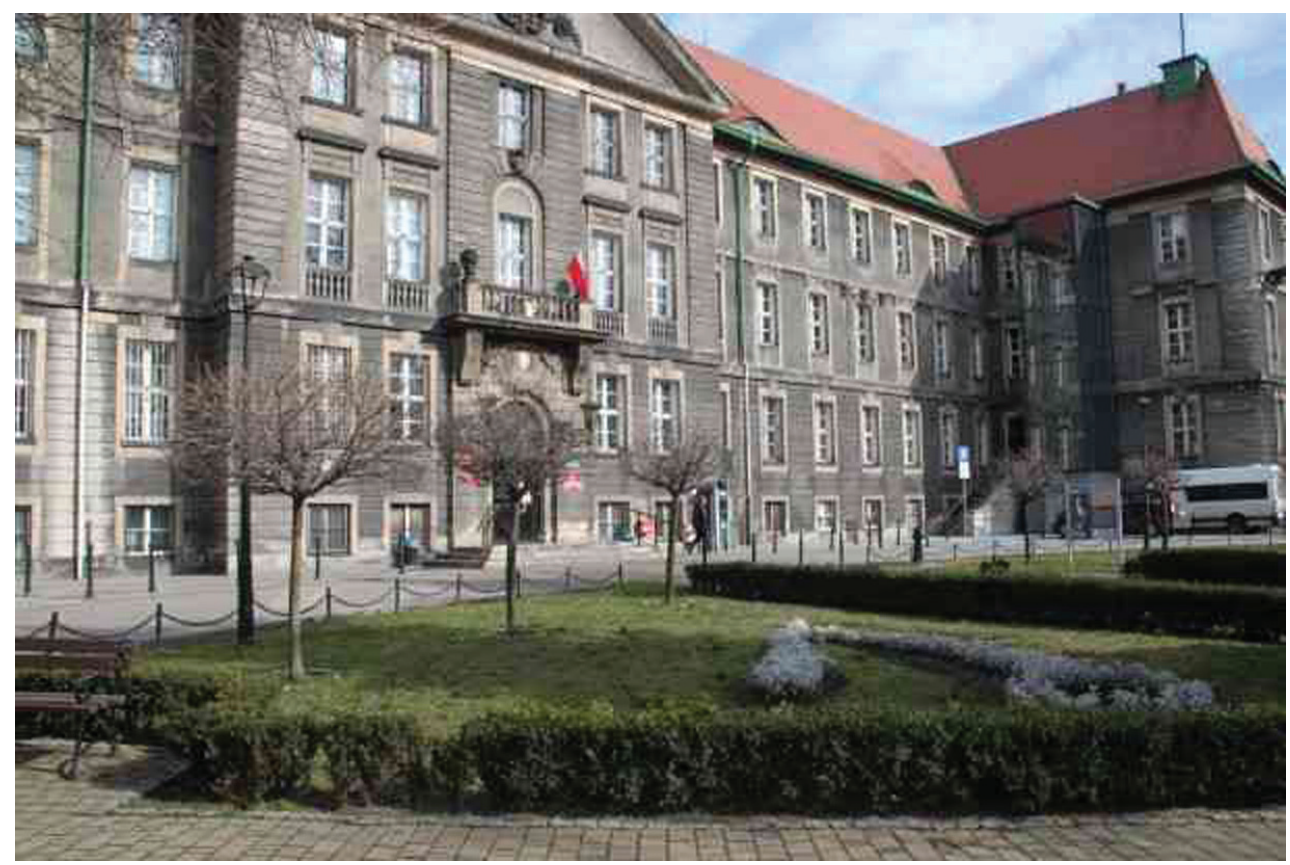

Fig. 10. Heinrich Brunnig Square and Memorial Plaque dedicated to the Senior Mayor of Bytom 1883-1919 Source: Photo by Author. 


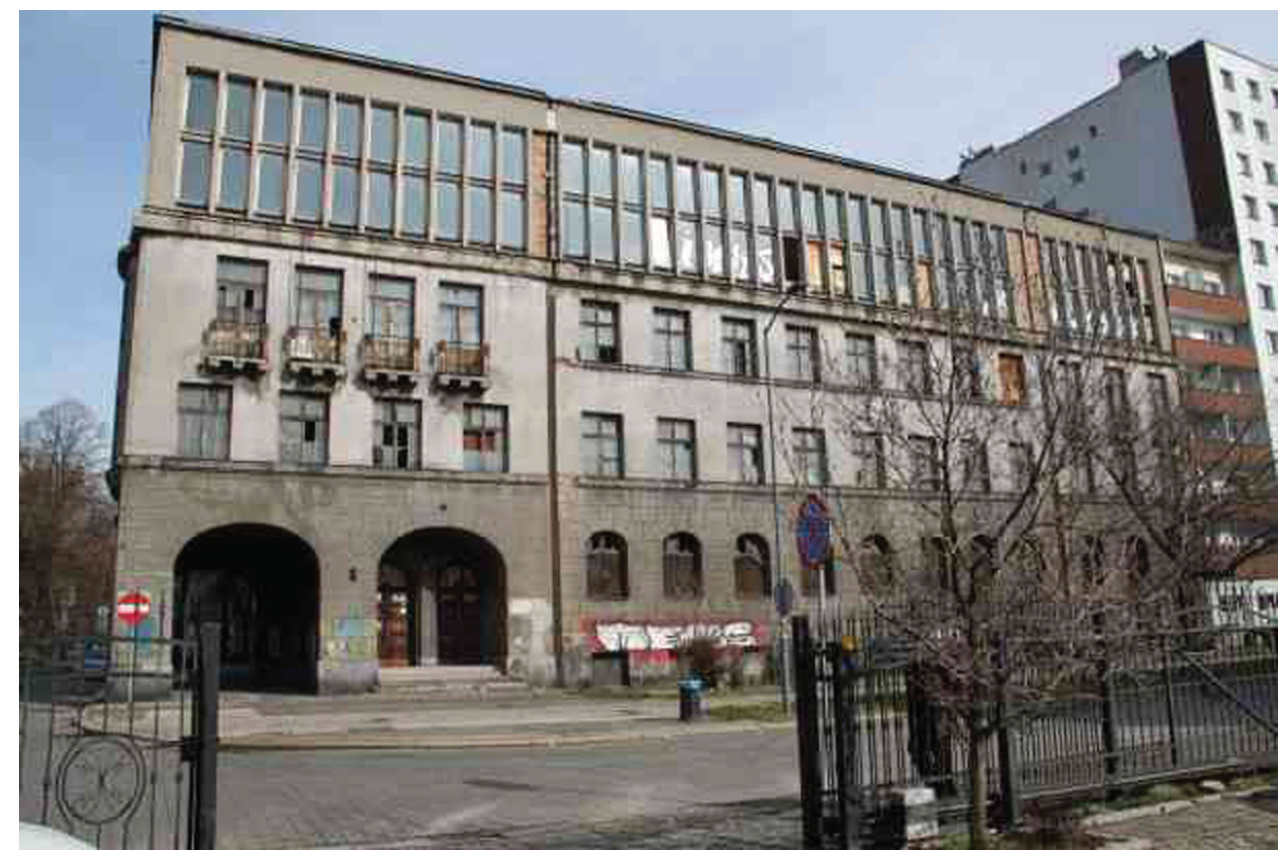

Fig. 11. Abandoned building of the former Polish United Workers' Party (PZPR)

Source: Photo by Author.

situated in place of the synagogue (Tab.1, Fig. 9). There appeared boards commemorating Silesian uprisings and the participation of local residents in these uprisings. Since the 1990s, subsequent anniversaries of the so-called Upper Silesian Tragedy have been commemorated.

Places of conflict and places of memory have remained, such as destroyed mining monuments in the centre, the unreconstructed city hall, the destroyed synagogue, the abandoned building of the former Polish United Workers' Party (PZPR), and abandoned quarters of Soviet soldiers (Fig. 6, 11).

Today, 167,000 people live in Bytom. Apart from Poles who dominate in terms of their number and culture, several groups of residents cultivating a particular cultural and historical identity may be distinguished (Narodowy Spis Powszechny Ludności i Mieszkań, 2011).

One of these groups is represented by the German minority. The activity of its members in the public sphere is visible through the organisation of cultural events related to the history of Bytom's Germans. The group's social media page has approximately 500 fans and members. Even though conflicts of high social resonance are rare, in 2015 there arose a serious political provocation caused by the "Association of Youth of the German Minority". In the parish cemetery in Bytom, a memorial was unveiled commemorating soldiers of the $3^{\text {rd }}$ Reich and members of the Selbstschutz and Freikorps formations. The head of the Bytom Association of Youth of the German Minority was behind this. The initiative was supported by, among others, a Bundestag deputy from the right-wing Alternative for Germany party (Alternative für Deutschland), who co-financed the memorial. The memorial was destroyed on the same day. The incident was met with a severe response from the Polish Institute of National Remembrance as well as from well-known German historians (Bijak, 2019).

Apart from this, the city exists as a kind of virtual community in the culture and memory of the resettled living in Recklinghausen, Duisburg, Bochum, Gelsenkirchen in Rhine-Westphalia and in other cities in Germany. This refers to former German citizens of Bytom, who moved to Germany directly after World War II or in the following decades, under political treaties and afterwards in order to join families. Their activity is reflected on numerous Internet forums, in meetings and in creative work. From generation to generation, they pass on to each other the addresses of houses where they used to live, photographs and stories (Heffner, 1999). They frequently visit the city and friends who live in Bytom, taking care of cemeteries and visiting places where they and their parents came from.

The most close-knit group is that of Silesians (of families living in the city for many generations). The informal centre of Silesian culture is located at Saint Jacobs's parish, which houses collections of regional outfits, interior decor, prayer books, etc. Lessons of the Silesian dialect (Ślůnsko godka) are organized there. The percentage of people in Bytom who chose the Silesian national and ethnic identity during the 
population census of 2011, according to the Central Statistical Office (GUS), amounted to $17.6 \%(31,109$ people). In the population census of 2011 , for the first time in the history of the Polish general census, residents of the country could express complex national and ethnic identities. The general census of 2011 included two questions making it possible to express complex national and ethnic identities:

1. "What is your nationality?"

2. "Do you also feel an affiliation to another nation or ethnic community?") (Narodowy Spis 2012).

Those from the Eastern Borderlands and their descendants still account for a considerable percentage of residents. The Association of People from the Borderlands in Bytom is active in social media, declaring educational activities in its statute. The Borderland People in Bytom regained the Bytom lion and, as a gesture of reconciliation, brought it to Bytom, returning the sculpture to the city in an honourable place on the Market Square. The activity of the Borderland People, their children and grandchildren in the space of Bytom is particularly evident on 1 November, as they raise money for the maintenance of Lviv cemeteries in which Poles are buried.

Another group emphasising its presence in the space of Bytom is that of the Roma people. There are several hundred Roma people in Bytom. The Roma community is concentrated in devastated tenement houses in the poorest parts of the centre of Bytom. Despite social programs, self-government organisations and involvement of social workers, the course of adaptation remains slow.

\section{Conclusion}

The conducted research on the evolution of the identity of Upper Silesian Bytom, Southern Poland and its spatial aspects has demonstrated its richness and multifaceted character, as well as contradictions. Despite the imposition, and in the case of Bytom - the generation of identity for political purposes, the tangible history of the city is continuous. The conflicts, mainly national and political, are expressed in frequent changes in identity policy which are visible, among others, in the commemorative names of streets, monuments and memorials.

The symbolic spaces, squares and main streets have changed their names several times over the studied period, reflecting the reigning nation and political system. The ethnic affiliation of residents of the city, their languages and observed religions have changed (Fig. 9). The city remains as a material framework for human activity. Elements of the cultures developing in it have been recorded in its material shape and landscape. Today, the identity of the city retains the nature of representation of values which are valid for its residents, supporters living in Germany and economic emigrants. Significant is the fact that the identity broken in 1945 is being revived, as there is a group of residents in Bytom who lived in Germany but returned for their retirement or who declare an intention to return to Bytom. The process of formation of the new identity of the city is not simple; it may be broken and will certainly need time and goodwill from the major local entities shaping this identity. Polish membership in the European Union, a guarantor of integration processes on the continent, is a conducive factor of these processes. One may dare to claim that Bytom, for the first time in several hundred years, has been given the opportunity to create the identity of the city based on respect for humanist values formed by different nations in various periods of its history. Open debate is leading to recognition of its rich past which, despite some irreversible losses, has survived and is reflected in the urban space, reminding us of the diversity of cultures which have shaped the city.

\section{References}

Adamkiewicz S., 2013, Wstydliwa historia, czyli rzecz o bytomskim Iwie, 2013 (Eng. A shameful story, or a story about a lion from Bytom, 2013), Wolne Media, https://wolnemedia.net/wstydliwa-historia-czyli-rzecz-o-bytomskimIwie/ (accessed: 25 February 2020).

Antonsich M., Hoyler, M., 2019, Urbanism and geopolitics: The missing links, Political Geography, 70, 145-147. doi. org/10.1016/j.polgeo.2018.10.006.

Baker A., 1996, Introduction: the identifying of spaces and places, [in:] D. Vanneste (ed), Space and Place. Mirrors of Social and Cultural Identities?, Geografisch Instituut Katholieke Universiteit Leuven, Leuven, 1-2.

Bauman Z., 1998, Globalisation: the human consequences, Polity Press, Cambridge.

Beuthen Illustrierter Fuhrer durh das Oberschlesische Industriegebiet. Beuthen. Plan. 1914 (Eng. Beuthen Illustrated guide through the Upper Silesian industrial area. Bytom. Plan 1914), 1914, Woerl's Reisebücherverlag, Leipzig.

Beuthen in Oberschleslesien 1927. Stadtvermessungsamt. Masstab 1:8000. (Eng. Bytom in Upper Silesia 1927. City survey office. Scale 1: 8000), 1927, Anst.v. Bogdan Gisevius, Berlin.

Beuthen O.S. 1941. Stadtvermessungsamt. Masstab 1:10000. 1941 (Eng. Bytom in Upper Silesia 1941. City survey office. Scale 1: 8000), 1941, Wilgrö-Scharf Druck von Willy Größchen, Dortmund.

Białasiewicz L., 2002, Upper Silesia: Rebirth of a Regional Identity in Poland, Regional \& Federal Studies, 12(2), 111-132. doi: $10.1080 / 714004749$ 
Bijak S., 2019, Na cmentarzu w Bytomiu pojawiła się szokująca tablica w języku niemieckim. Jednak zniknęła (Eng. A shocking plaque in German has appeared at the cemetery in Bytom. However, it has disappeared), Dziennik Zachodni 24.11.2019, https://dziennikzachodni.pl/nacmentarzu-w-bytomiu-pojawila-sie-szokujaca-tablica-wjezyku-niemieckim-jednak-zniknela/ar/c1-14601399 (accesed: 25 February 2020).

Buśkiewicz J., 2013. The occupation of Bytom by the Red Army. The state of the infrastructure, town destruction after freeing and rebuild of industry, [in:] S. Fertacz, M.W. Wanatowicz (eds.), The Old and the New Ages. Vol. 2(7), Wydawnictwo Uniwersytetu Śląskiego, Katowice, 93-103.

Cohen B., Müller B., 2016, A teacher and his students: child Holocaust testimonies from early postwar Polish Bytom, East European Jewish Affairs, 46(1), 68-115. doi: 10.1080/13501674.2016.1153878

Cyganie/Romowie w Polsce i w Europie: wybrane problemy historii i współczesności (Eng. Gypsies / Roma in Poland and Europe: selected problems of history and the present), 2011, Biuro Analiz i Dokumentacji. Zespół Analiz i Opracowań Tematycznych. OT-603, Kancelaria Senatu RP, Warszawa.

Drabina J., 2010, Dzieje Bytomia (Eng. History of Bytom), Wydawnictwo Towarzystwa Miłośników Bytomia, Bytom.

Fenton S., 2007, Etniczność (Eng. Ethnicity), Sic., Warszawa.

Harvey D.C., 2001, Heritage Pasts and Heritage Presents: temporality, meaning and the scope of heritage studies, International Journal of Heritage Studies, 7(4), 319-338. doi: 10.1080/13581650120105534

Heffner K., 1999, The Return of Emigrants from Germany to Upper Silesia: Reality and Prospects, [in:] K. Iglicka, K. Sword (eds.), The Challenge of East-West Migration for Poland, Palgrave Macmillan, London, 168-205. doi: 10.1007/978-1-349-27044-6_9

Kamusella T.D., 1999, Ethnic Cleansing in Silesia 195089 and the Ennationalizing Policies of Poland and Germany, Patterns of Prejudice, 33(2), 51-73. doi: 10.1080/003132299128810551

Kamusella T.D., 2000, Wyłanianie się grup narodowych i etnicznych na Śląsku w okresie 1848-1918 (Eng. The emergence of national and ethnic groups in Silesia in the period 1848-1918), Sprawy Polityczne, 2(2), 63-118.

Kamusella T.D., 2012, Poland and the Silesians: Minority Rights à la carte, Journal on Ethnopolitics and Minority Issues in Europe, 11(2), 42-74.

Kisiel P., 2019, Unwanted inheritance? Industrial past as the EU heritage, International Journal of Heritage Studies, 26, 1-15. doi: 10.1080/13527258.2019.1678053

Konieczny A., 1977, Przygotowania władz hitlerowskich do ewakuacji Górnego Śląska w końcowej fazie II wojny światowej (Eng. Preparations of the Nazi authorities for the evacuation of Upper Silesia in the final phase of World War II), Studia Ślaskie, 32, 261-279.

Krzysztofik R., Runge J., Kantor-Pietraga I., 2011, Paths of Shrinkage in the Katowice Conurbation. Case Studies of Bytom and Sosnowiec Cities. Wydawnictwo Wydziału Nauk o Ziemi, Uniwersytetu Śląskiego, Sosnowiec.
Lamparska M., 2013, Uwarunkowania rozwoju turystyki postindustrialnej w przestrzeni Górnośląskiego Zwiqzzu Metropolitalnego (Eng. Conditions for the development of post-industrial tourism in the space of the Upper Silesian Metropolitan Union). Wydawnictwo Uniwersytetu Śląskiego, Katowice.

Lippóczy P., Walichnowski T., 1982, Przesiedlenie ludności niemieckiej z Polski po Il wojnie światowej w świetle dokumentów (Eng. The resettlement of the German population from Poland after World War II in the light of documents), Państwowe Wydawnictwo Naukowe, Warszawa.

Łempiński Z., 1979, Przesiedlenie ludności niemieckiej z województwa śląsko-dąbrowskiego w latach 1945-1950 (Eng. Resettlement of the German population from the ŚląskoDąbrowski Voivodeship in the years 1945-1950), Śląski Instytut Naukowy, Katowice.

Madurowicz M., 2017, Ciągłość miasta. Prolegomena (Eng. City continuity. Prolegomena), Wydawnictwo Uniwersytetu Warszawskiego, Warszawa.

Massey D.S., Arango J., Graeme H., Kouaouci A., Pellegrino A., Taylor J.E., 1993, Theories of International Migration: A Review and Appraisal, Population and Development Review, 19(3), 431-466. doi: 10.2307/2938462

Michałkiewicz S. (ed.), 1976, Historia Śląska. Tom III, część 1, 1850-1918 (History of Silesia, volume 3, part 1, 18501918), Ossolineum, Wrocław.

Mitchell D., 2005, Landscape, [in:] D. Atkinson, P. Jackson, D. Sibley, N. Washbourne (eds.), Cultural Geography. A Critical Dictionary of Key Concepts, L.B. Tauris, London, 49.

Molenda D., 1972, Kopalnie Rud Ołowiu na terenie złóż ślqsko-krakowskich w XVI-XVIII (Eng. Lead Ore Mines in the Silesian-Kraków deposits in the 16th-18th centuries), Ossolineum, Wrocław-Warszawa-Kraków-Gdańsk.

Monnet J., 2011, The symbolism of place: a geography of relationships between space, power and identity, European Journal of Geography / Politique, Culture, Représentations, article 562. doi: 10.4000/cybergeo.24747

Murzyn-Kurpisz M., Gwozdż K., 2011, The changing identity of the Central European city: the case of Katowice, Journal of Historical Geography, 37(1), 113-126. doi: 10.1016/j. jhg.2010.04.001

Narodowy Spis Powszechny Ludności i Mieszkań (Eng. National Census of Population and Housing), 2011, https://stat. gov.pl/cps/rde/xbcr/gus/LUD_ludnosc_stan_str_dem_ spo_NSP2011.pdf (accessed: 02 March 2020).

Nawrocki, T., 2010, Od rynku do mallu. Zmiany centrów miast śląskich i ich społeczna percepcja (Eng. From the market square to the mall. Changes in the centers of Silesian cities and their social perception), Studia Etnologiczne i Antropologiczne, 10, 164-176.

OpenStreetMap contributors, 2020 OpenStreetMap data, https://openstreetmap.org (accessed: February 2020).

Paasi A., 2001, Europe as a Social Process and Discourse: Considerations of Place, Boundaries and Identity, European Urban and Regional Studies, 8(1), 7-28. doi: 10.1177/096977640100800102

Plan-informator miasta Bytomia w 1947, 1947, (Eng. Planguide of the city of Bytom in 1947), Starostwo Powiatowe. Bytom. 
Polak-Springer P., 2012, Landscapes of Revanchism: Building and the Contestation of Space in an Industrial Polish-German Borderland, 1922-1945, Central European History, 45(3), 485-522. doi:10.1017/S0008938912000362

Rampley M. (ed.), 2012, Heritage, Ideology, and Identity in Central and Eastern Europe: Contested Pasts, Contested Presents, Boydell \& Brewer, Martlesham-Rochester. doi:10.7722/j.ctt3fgmor

Rębowska K., 2002, Kultura w tradycji i we współczesnych nurtach badań geograficznych (Eng. Culture in tradition and in contemporary geographic research trends), Wydawnictwo Uniwersytetu Łódzkiego, Łódź.

Schofer L.,1975, The formation of a modern labor force Upper Silesia 1865-1914, University of California Press Berkeley, Los Angeles-London.

Tkocz M., 1998, Restrukturyzacja przemysłu regionu tradycyjnego (Eng. Traditional region industry restructuring), Wydawnictwo Uniwersytetu Śląskiego, Katowice.

Tuan Y.-F., 1977, Space and Place: the perspective of experience, The University of Minnesota Press, Minneapolis.

Ufer U., 2015, Urban access. Contested spaces and contested politics, Focaal - Journal of Global and Historical Anthropology, 72, 64-77. doi:10.3167/fcl.2015.720106

Ustawa z dnia 6 stycznia 2005 r. o mniejszościach narodowych $i$ etnicznych oraz o języku regionalnym (Eng. The Act of January 6, 2005 on National and Ethnic Minorities and Regional Language), 2005, (Dz.U. 2005 nr 17 poz. 141). 